\title{
The Intangible Resources and Small Firms' Multilevel Performance: A Partial Least Squares Approach
}

\author{
Mohammed Ibrahim Aminu ${ }^{1}$, Rosli Mahmood ${ }^{1} \&$ Farrah Merlinda Muharram $^{1}$ \\ ${ }^{1}$ School of Business Management, College of Business, Universiti Utara Malaysia, Sintok, Kedah, Malaysia \\ Correspondence: Mohammed Ibrahim Aminu, School of Business Management, College of Business, Universiti \\ Utara Malaysia, Sintok, Kedah, Malaysia. E-mail: miaminuscholar@yahoo.com
}

Received: February 20, 2015

Accepted: May 19, 2015 Online Published: June 13, 2015

doi:10.5539/ass.v11n16p187

URL: http://dx.doi.org/10.5539/ass.v11n16p187

\begin{abstract}
Previous literature testified the impact of both intellectual capital and entrepreneurial orientation on small firm performance, but the studies generally ignore the combined effect of such intangible resources on multilevel performance (i.e., financial and non-financial performance) which is the appropriate measurement system of performance. Hence, this study designed to address this issue by investigating the impact of such intangible resources on the aforesaid performance of 302 registered small and medium firms in Nigerian. To analyze the data, variance based structural equation model was employed using SmartPLS3. Consequently, the analysis established the empirical evidence of the positive significance effects of all dimensions of intellectual capital and entrepreneurial orientation on multilevel performance.
\end{abstract}

Keywords: intellectual capital, entrepreneurial orientation, multilevel performance, small firms

\section{Introduction}

Entrepreneurship literature recognizes the impact of intangible firm's resources as a major determinant of firm performance. Among the popular paradigms that explain such relationship is a resource-based view (Barney, 1991; Bridoux, 2003). This perspective supposes that if all firms share the same resources, then none of them is having a possibility of sustained competitive advantage. This is because, as one firm is able to conceive of and implement a strategy that can improve its performance, the other firms can also do the same as they possessed everything in common. Thus, the source of sustained competitive advantage according to Barney (1991), is for a firm to have heterogeneous intangible valuable, rareness, inimitable and non-substitutable assets to be used in implementing strategy which is not simultaneously being implemented by current or potential competitors and also difficult to be duplicated.

However, some of the major constructs which have been conceptualized and empirically testified as those intangible resources which explain under the framework of resource-based perspective are intellectual capital (Roos \& Roos, 1997) and entrepreneurial orientation (Shane, Mcgrath, \& Macmillan, 2009). The impact of both of these resources was empirically proven by a number of researchers on small and medium firms (Lumpkin \& Dess, 2001; Sumedrea, 2013; Walsh, Enz, \& Canina, 2008; Wiklund \& Shepherd, 2005; Wiklund \& Shepherd, 2003). Nevertheless, upon all the existing evidence of such relationships, there are very rare studies on how both intellectual capital and entrepreneurial orientation impact multilevel performance (i.e., both financial and non-financial performance). Financial and non-financial measurement system considered the most appropriate way of measuring today's performance (Kaplan \& Norton, 1992) as against the traditional financial measures, which is solely concerned with historical nature of the firm (Bourguignon, Malleret, \& Nørreklit, 2004; Norreklit, 2000), and that can, of course, give misleading indicators for today's competitive environment (Kaplan \& Norton, 1992; Suwignjo, Bititci, \& Carrie, 2000).

However, to determine such modern day's performance, firms ought to have both the knowledge assets (Denicolai, Zucchella, \& Strange, 2014) and also entrepreneurial resources, which are crucial part of their survival and success (Lyon, Lumpkin, \& Dess, 2000). Consequently, some scholars recommended that knowledge assets should be investigated with other firm's intangible assets (Denicolai et al., 2014). Similarly, Nieves and Haller (2014) suggested that other variables that are investigated on the performance in previous studies could be investigated alongside knowledge resources to determine performance. Hence, this study is designed to address this knowledge gap by investigating the impact of intellectual capital (IC) and 
entrepreneurial orientation (EO) on multilevel performance on a sample of small and medium enterprises in Nigeria. The study is basically made up of six sections, the next section concerned with the background and hypothesis. While section three explained the methodology on which the study built-on, section four presented the analysis of the result. In section five, discussion, conclusions, and research implications are presented, and finally limitations and direction for future research are presented in the last section.

\section{Background and Hypothesis}

\subsection{Intellectual Capital and Performance}

Intellectual capital (IC) refers to intangible benefits accessed by a particular firm, which is generated from its workforce and the relationships it established with other external groups (Gowthorpe, 2009). It is also a set of intangibles assets which sources performance and value creation (Gogan \& Draghici, 2013). However, the pool of previous studies viewed the concept as multidimensional construct which consists of three dimensions (Campbell \& Abdul Rahman, 2010; Gogan \& Draghici, 2013; McPhail, 2009; Roos \& Roos, 1997). These are (1) human capital, (2) structural or organizational capital, and (3) relational or customer capital (Castro \& Sáez, 2008; Díez, Ochoa, Prieto, \& Santidrián, 2010; Lu \& Hung, 2011; Sydler, Haefliger, \& Pruksa, 2013). However, a clearer understanding of the concept of IC and its impact on performance could be best explained on the basis of these components or dimensions which constitute the concept (Marcin, 2013).

\subsubsection{Human Capital}

Human capital is one of the crucial form of intangible knowledge assets which resides within individual employees (Nieves \& Haller, 2014). It is a personal information or knowledge stock of the firm that is represented by its employees and sources of strategic innovation and invention which consists some elements such as experience, skill, business knowledge, education, creativity and employees' satisfaction (Yildız, Meydan, \& Güner, 2014). It also comprises knowledge's stock of capital skills, attitudes, and intellectual agility of employees at all levels and their ability to make good decisions, deal with the problems, as well as creating and maintaining good interpersonal relationships (Gogan \& Draghici, 2013). Other assets composed of this dimension of IC includes information and data held by employees, their technical ability as well as personal traits such as ability to learn, desire to share information, imagination and creativity, participating and commitment to overall firm's goals and objectives (Marcin, 2013).

\subsubsection{Structural Capital}

On the other hand, structural capital refers to sum total of organizational capabilities which are considered to be owned by the business and enable it to meet its market requirements (Yildız et al., 2014), and therefore remains with the firm even when the employees leave, as it is generally explicit and owned by the business independently from its employees (Sydler et al., 2013). It is a form of capital which contains both organizational and technological elements which pursue the integration and coordination of activities within the firm (Castro \& Sáez, 2008). These elements of structural capital include intellectual property, culture, systems and processes (Yıldı et al., 2014), databases and computer networks, equipment structure, management style or software as well organizational culture (Gogan \& Draghici, 2013).

\subsubsection{Relational Capital}

Relational capital gathers the value of that relationship which a firm acquires and maintains with external environmental agents (Castro \& Sáez, 2008; Gogan \& Draghici, 2013). It is the information which is grounded within market channels which the firm developed through business and customer relations (Yıldız et al., 2014), and entirety of the value of the relationships between firm with people and organizations with which it conducts its business (Sydler et al., 2013). Castro and Sáez (2008) argued that, relational capital is also concerned with both business capital, i.e., value of firm's relationships which involved the agents of its basic business activities and processes such as customers, suppliers, and allies, and the social capital which refers to the value of the firm's relationships with its surroundings and other social agents. Other elements of relational capital include the relationships of the firm with its clients and business partners (Gogan \& Draghici, 2013), and most importantly customer relationships such as image building and customer loyalty, and the branding, such as preference, reputation, attitude and brand recognition (Sydler et al., 2013).

However, these stocks of intangible knowledge assets are some of those valuable rare, inimitable and non-substitutable firm's assets (Roos \& Roos, 1997) which constitutes the firm's sources of competitive advantage and performance (Barney, 1991). Nieves, Quintana, and Osorio (2014) noted that the ability of a firm to stimulate and improve the level of these knowledge assets would put it in a better position to address any competitive difficulties. Thus, based on the above discussion, the following hypotheses are formulated: 


\section{H1: There is significant positive relationship between human capital and multilevel firm performance}

H2: There is significant positive relationship between structural capital and multilevel firm performance

H3: There is significant positive relationship between relational capital and multilevel firm performance

\subsection{Entrepreneurial Orientation and Performance}

EO refers to the strategic orientation of a firm which captures the specific aspects of a firm's decision-making styles, practices and methods (Wiklund \& Shepherd, 2005). Miller's (1983) conceptualization has initially identified three basic dimensions, innovation, risk-taking, and proactiveness. In another development, Lumpkin and Dess (1996) delineated five dimensions of entrepreneurial orientation. In other words, Lumpkin and Dess (1996) added two more dimensions of competitive aggressiveness and autonomy to the first three (i.e., innovation, risk-taking, and proactiveness) to make them five dimensions of EO. As the present study drawn on Miller's (1983) theorization and conceptualization of entrepreneurial orientation (EO), the research adheres to adopt these first three dimensions of EO construct and test the effect of each dimension independently on performance as suggested by Mahmood and Hanafi (2013).

\subsubsection{Innovativeness}

Wang et al. (2001) held that innovativeness is the effort of the firm in finding new opportunities and new solutions. This involves an experimentation and creativity which will result in new goods and services or improving technological processes. However, in today's rapid and unpredicted changes in business environment, effectiveness in producing, assimilating as well as exploiting innovation cannot be overemphasized. In other words, innovativeness is the willingness of a firm to support the creativity, new ideas as well as experimentation in producing goods and services (Mahmood \& Hanafi, 2013), and also concerned with the openness of a firm to new ideas (Pratono et al., 2013). Wang et al. (2001) further posited that the firm's innovativeness can be in many forms, such as technological innovativeness (efforts on research and engineering in order to develop new goods and services as well as process), product-market innovativeness (market research, market segmentation, product designed, advertisement and promotions), and administrative innovativeness (innovations in management systems, organizational structure and control techniques).

\subsubsection{Risk-taking}

Risk-taking is concerned with bold actions by venturing into an unknown, borrowing heavily, or committing considerable resources to ventures into an uncertain market environment (Rauch, Wiklund, Lumpkin, \& Frese, 2009). It is the degree of the managers' ability and willingness to commit large and risky resources into an uncertain or unknown venture (Wang et al., 2001). Accordingly, such risk-taking could be in the form of risk preference, risk perception, and risk propensity. More so, risk-taking involves activities such as highly borrowing and a high percentage of resources commitments into uncertain projects and unknown markets (Lyon et al., 2000). Such risky investment, if succeeded, will possibly generate and yield a high return. In essence, a firm with managers who are so bold in taking business related risk are more likely to achieve and sustain competitive advantage over nonentrepreneurial firms which are characterized as risk-averse (Miller, 1983).

\subsubsection{Proactiveness}

Proactiveness is associated with seeking first mover advantage and forward-looking efforts to shape the firm's business environment resulting from introducing products and process ahead of competitors (Lyon et al., 2000). However, as a dimension of entrepreneurial orientation (EO), proactiveness refers to an opportunity-seeking, and forward-looking behavior which is characterized by an introduction of new products or services ahead of the competitors in an anticipation of expected future demand (Rauch et al., 2009). This includes an initiative effort and applying existing advantages in shaping the business environment and responding to competitive challenges (Wang et al., 2001). As such, the firm will always be the first to come up with proactive moves in terms of its products and beat other competitors (Miller, 1983).

Generally, entrepreneurial firms are firms where their top managers are entrepreneurially oriented as prove by their strategic decision and operating management philosophy (Covin \& Slevin, 1989). These authors argued that unlike conservative firms in which top level management decision is decidedly non-innovative, risk-averse and reactive, entrepreneurial oriented firms are characterized as those that are innovative, taking business-related risk and proactive in their decisions. These types of firms usually come up with new products, processes, and strategies ahead of their competitors. As a result, the non-entrepreneurial firms always imitate them instead of leading the way, and consequently entrepreneurial firms are in the good position for taking advantage of superior performance over their non-entrepreneurial rivals (Miller, 1983). 
Thus, the EO literature theorized that innovativeness, risk-taking, and proactiveness have a positive impact on financial and non-financial firm performance (Keh, Nguyen, \& Ng, 2007). Wang (2008) argued that EO is an ingredient firm's resource which determines its success. Huang, Wang, Chen, and Yien (2011) also maintained that, generally, there is the universal effect of those dimensions of EO on firm performance. However, a number of empirical studies supported this notion as they found significant relationship between EO and firm performance (Covin \& Slevin, 1989; Lumpkin \& Dess, 1996; Lumpkin \& Dess, 2001; Rauch et al., 2009). Moreover, although there is a lack of studies which investigate the impact of EO dimensions on both financial and non-financial performance, such relationship has also been established in the work of Keh et al. (2007). As such, in this study we hypothesized thus:

H4: There is significant positive relationship between innovativeness and multilevel firm performance

H5: There is significant positive relationship between risk-taking and multilevel firm performance

H6: There is significant positive relationship between proactiveness and multilevel firm performance

\section{Methodology}

\subsection{Design and Sample}

This study was designed as a quantitative approach which engaged in hypothesis testing of the causal relationship between predictor and criterion variables, which is commonly known as causal research (Sekaran \& Bougie, 2013). Generally, organizational researchers drawing on quantitative research often employ survey method as it is considered the most appropriate for collecting information on the predetermined instruments that yield statistical data on a large sample for the purpose of generalization (Creswell, 2003). The study is also on the basis of the cross-sectional method in which data collection was conducted over a single period of time. Hence, 302 usable data collected on Nigerian firms which are categorized as formal SMEs under the classification of Nigerian national policy on MSMEs (Small and Medium Enterprises Report, 2009), and the questionnaires were responded by managers/owners representing their various firms.

\subsection{Measures}

The measures for all constructs of this study were adapted from previous studies. For firm performance which is the dependent variable, eight items comprising both financial and non-financial measures (i.e., multilevel performance) were adapted from the work of Spillan and Parnell (2006). The performance in this study was hypothesized as a multilevel construct which comprises measures from different background (i.e., three financial and five non-financial indicators). Nevertheless, the construct is considered as a reflective-reflective type of the hierarchical component model (HCM). For human, structural, and relational dimensions of intellectual capital, twelve items were adapted from Castro and Sáez (2008). In this case, the first four items present the human capital, three for structural capital, and the last five for relational capital. Similarly, the nine items measuring innovativeness, risk-taking, and proactiveness dimension of entrepreneurial orientation were adapted from the work of Milovanović and Galetić (2008) which were developed based on the Knight's (1997) study. Each of the aforesaid dimensions of entrepreneurial orientation was measured using three items respectively. However, all of the twenty-nine items of this study were measured using Likert scale (1-7) ranging from strongly disagree to strongly agree. Finally, for both the preliminary and main analysis, Smart PLS3 was employed.

\section{Analysis of the Results}

Both the reliability and validity of this study was assessed using measurement model of structural equation modeling. The reliability analysis was measured using composite reliability, as shown in the Table 1 below, the reliability analysis for all constructs is above the threshold of .70, and the average variance extracted (AVE) which represents the convergent validity is also above the threshold of .50 (Hair, Hult, Ringle, \& Sarstedt, 2014). Similarly, the discriminant validity of the constructs is also presented in Table 2, where the square root of AVE (i.e., diagonal bolded figures) of all the variables is higher than the correlation between two variables, and thus, indicating the distinctiveness of each variable (Fornell \& Larcker, 1981). However, since the dependent variable (performance) is reflective-reflective type of HCM, we employed repeated indicator approach, thereby repeating the seven valid indicators of both financial and non-financial lower order components (LOCs) on performance which is the higher order component (HOC) as suggested by the HCM extant literature (Afthanorhan, 2014; Becker, Klein, \& Wetzels, 2012; Ringle, Sarstedt, \& Straub, 2012). Although financial and non-financial LOCs appeared in the research model, but LCOs are not taken into cognizance in both measurement and structural equation model, and therefore HOC represents the HCM in the analysis ( Hair et al., 2014). 
Table 1. Results of measurement model and convergent validity $(n=302)$

\begin{tabular}{|c|c|c|c|c|}
\hline Constructs & Items & Loadings & $\overline{A V E}$ & $\mathbf{C R}$ \\
\hline \multirow[t]{4}{*}{ Human Capital } & $\mathrm{HC} 01$ & 0.772 & 0.585 & 0.849 \\
\hline & $\mathrm{HC} 02$ & 0.777 & & \\
\hline & $\mathrm{HC} 03$ & 0.805 & & \\
\hline & $\mathrm{HC} 04$ & 0.701 & & \\
\hline \multirow[t]{3}{*}{ Structural Capital } & SC01 & 0.789 & 0.612 & 0.825 \\
\hline & $\mathrm{SC} 02$ & 0.813 & & \\
\hline & $\mathrm{SC} 03$ & 0.743 & & \\
\hline \multirow[t]{3}{*}{ Relational Capital } & $\mathrm{RC} 02$ & 0.752 & 0.580 & 0.806 \\
\hline & $\mathrm{RC} 04$ & 0.761 & & \\
\hline & $\mathrm{RC} 05$ & 0.773 & & \\
\hline \multirow[t]{3}{*}{ Innovativeness } & INN01 & 0.783 & 0.582 & 0.807 \\
\hline & INN02 & 0.750 & & \\
\hline & INN03 & 0.756 & & \\
\hline \multirow[t]{3}{*}{ Risk-Taking } & RT01 & 0.776 & 0.581 & 0.806 \\
\hline & RT02 & 0.762 & & \\
\hline & RT03 & 0.748 & & \\
\hline \multirow[t]{3}{*}{ Proactiveness } & PR01 & 0.782 & 0.652 & 0.849 \\
\hline & PR02 & 0.876 & & \\
\hline & PR03 & 0.760 & & \\
\hline \multirow[t]{7}{*}{ Performance } & FP01 & 0.800 & 0.646 & 0.927 \\
\hline & FP02 & 0.854 & & \\
\hline & FP03 & 0.851 & & \\
\hline & FP04 & 0.777 & & \\
\hline & FP05 & 0.774 & & \\
\hline & FP06 & 0.806 & & \\
\hline & FP08 & 0.759 & & \\
\hline
\end{tabular}

Note: Items RC01, RC03, and FP07 were deleted due to low loadings.

Table 2. Results of measurement model and discriminant validity $(\mathrm{n}=302)$

\begin{tabular}{llllllll}
\hline Constructs & $\mathbf{1}$ & $\mathbf{2}$ & $\mathbf{3}$ & $\mathbf{4}$ & $\mathbf{5}$ & $\mathbf{6}$ & $\mathbf{7}$ \\
\hline 1 Human Capital & $\mathbf{0 . 7 6 5}$ & & & & & & \\
2 Structural Capital & 0.670 & $\mathbf{0 . 7 8 2}$ & & & & & \\
3 Relational Capital & 0.729 & 0.733 & $\mathbf{0 . 7 6 2}$ & & & & \\
4 Innovativeness & 0.552 & 0.610 & 0.619 & $\mathbf{0 . 7 6 3}$ & & & \\
5 Risk-taking & 0.542 & 0.516 & 0.504 & 0.634 & $\mathbf{0 . 7 6 2}$ & & \\
6 Proactiveness & 0.677 & 0.679 & 0.691 & 0.723 & 0.589 & $\mathbf{0 . 9 2 1}$ & \\
7 Performance & 0.639 & 0.594 & 0.543 & 0.650 & 0.622 & 0.678 & $\mathbf{0 . 8 0 4}$ \\
\hline
\end{tabular}

The elements on the diagonal (bold headed) correspond to the square root of the AVE of the construct.

To test the proposed hypotheses, structural equation modeling (SEM) using partial least square method was employed. As shown in Table 3, all the predictors of the model have significant relationships with the criterion variable by looking at the path coefficient (Beta) and T Statistics. Specifically, the human capital is significantly related to performance $(\beta=0.273, p<0.01)$, as such $\mathrm{H} 1$ is supported. The structural capital on the other hand, is positively related to performance $(\beta=0.117, \mathrm{p}<0.10)$, whereas, relational capital is significantly related to multilevel performance $(\beta=0.141, p<0.05)$ respectively. Consequently, the statistical data supported $\mathrm{H} 2$ and $\mathrm{H} 3$ hypothesized relationships. On the dimensions of entrepreneurial orientation, the empirical data indicate the significant positive relationship between innovativeness and performance $(\beta=0.212, p<0.01)$, risk-taking and performance $(\beta=0.214, p<0.01)$, and proactivness and performance $(\beta=0.232, p<0.01)$. Thus, these statistical 
results indicate that hypotheses $\mathrm{H} 3, \mathrm{H} 4$, and $\mathrm{H} 5$ are also supported. However, the $R^{2}$ value for the whole model is 0.595 ; therefore it is clearly that these variables explain the high level of variance in firm multilevel performance, which is about $60 \%$.

Table 3. Results of structural model $(n=302)$

\begin{tabular}{llllll}
\hline Hypotheses & Relationships & Std Beta & SE & t-values & Decision \\
\hline H1 & Human Capital ->Performance & 0.273 & 0.055 & $4.936^{* * *}$ & Supported \\
H2 & Structural Capital ->Performance & 0.117 & 0.063 & $1.861^{*}$ & Supported \\
H3 & Relational Structural ->Performance & 0.141 & 0.070 & $2.014^{* *}$ & Supported \\
H4 & Innovativeness -> Performance & 0.212 & 0.064 & $3.300^{* * *}$ & Supported \\
H5 & Risk-taking -> Performance & 0.214 & 0.050 & $4.270^{* * *}$ & Supported \\
H6 & Proactiveness ->Performance & 0.232 & 0.070 & $3.305^{* * *}$ & Supported \\
\hline
\end{tabular}

$* * * \mathrm{p}<0.01 ; * * \mathrm{p}<0.05 ; * \mathrm{p}<0.1$

\section{Discussion and Conclusions}

This study investigated the effects of intangible firm resources on the multilevel performance of small and medium firms in Nigeria. This relationship has been theorized and supported by the resource-based perspective (Barney, 1991). However, although some studies investigated the impact of both intellectual capital and entrepreneurial orientation on performance of small firms, studies were not conducted to examine the combined effect of intellectual capital and entrepreneurial orientation on such small firms. More so, even the studies carried out on either intellectual capital on performance or entrepreneurial orientation on performance are often concerned with a single dimension of performance, thereby neglecting other vital components of the concept.

Consequently, this study investigated such relationship. The data of the study analysis provide the empirical evidence of positive significant relationship between human, structural, relationship capital and performance concept of this model, and these results are consistent with some previous findings in the extant intellectual capital literature (Abdullah \& Sofian, 2012; Kamukama, Ahiauzu, \& Ntayi, 2010; Díez et al., 2010). Although all of the three dimensions of intellectual capital are significantly related to multilevel firm performance, human capital has more impact on multilevel performance than structural and relational capitals. However, this is not surprising as some previous findings concluded that human capital has more influence on performance than other forms of intellectual capital (Bontis, Keow, \& Richardson, 2000; Castro \& Sáez, 2008). For the dimensions of entrepreneurial orientation on the other hand, as consistent with a number of research (Covin \& Slevin, 1989; Keh et al., 2007; Wang, 2008), innovativeness, risk-taking, and proactiveness are found to be highly significant to the performance of this study. Conclusively, this study shades some light on how intangible knowledge assets and entrepreneurial posture are contributing significantly to the small firms' multilevel performance. By implication, these firms are therefore encouraged to inculcate entrepreneurial orientation and develop the intellectual capital as their source of competitive advantage and superior performance.

\section{Limitations and Future Research}

As with many deductive studies, this study has some limitations. One of the major limitations of this study is that, the analysis took into consideration of only intellectual capital as a form of knowledge assets. Thus, future study should consider incorporating other forms of knowledge resources such as organizational knowledge. Secondly, as unpredictable changes and environment turbulence continue to dominate today's business strategy, entrepreneurial firms should embark on new strategies by reconfiguring their intangible resources to build a new source of superior performance. Hence, future research ought to be conducted on how a firm's existing resources can be integrated, rebuilt, and reconfigured to determine performance in a turbulent setting. Finally, this research is conducted as a cross-sectional, due to a number of challenges, such as cost, time and other scarce resources, and as such, future study may conduct longitudinal research to extend the understandings.

\section{References}

Abdullah, D. F., \& Sofian, S. (2012). The Relationship between Intellectual Capital and Corporate Performance. Procedia-Social and Behavioral Sciences, 40(6), 537-541. http://dx.doi.org/10.1016/j.sbspro.2012.03.227 
Afthanorhan, W. M. A. B. W. (2014). Hierarchical component using reflective-formative measurement model in partial least square structural equation modeling (Pls-Sem). International Journal of Mathematics, 2(2), 33-49. Retrieved from http://www.ijmsi.org/Papers/Volume.2.Issue.2/Version-1/H0221055071.pdf

Barney, J. (1991). Firm resources and sustained competitive advantage. Journal of Management, 17(1). http://dx. doi.org/10.1177/014920639101700108

Becker, J. M., Klein, K., \& Wetzels, M. (2012). Hierarchical latent variable models in PLS-SEM: Guidelines for using reflective-formative type models. Long Range Planning, 45(5-6), 359-394. http://dx.doi.org/10.1016/j. lrp.2012.10.001

Bontis, N., Keow, W. C. C., \& Richardson, S. (2000). Intellectual capital and business performance in Malaysian industries. Journal of Intellectual Capital, 1(1), 85-100. http://dx.doi.org/10.1108/14691930010324188

Bourguignon, A., Malleret, V., \& Nørreklit, H. (2004). The American balanced scorecard versus the French tableau de bord: The ideological dimension. Management Accounting Research, 15(2), 107-134. http://dx. doi.org/10.1016/j.mar.2003.12.006

Bridoux, F. (2003). A Resource-Based Approach to Performance and Competition: An Overview of the Connections between Resources and Competition. Belgium.

Campbell, D., \& Rahman, M. R. A. (2010). A longitudinal examination of intellectual capital reporting in Marks \& Spencer annual reports, 1978-2008. The British Accounting Review, 42(1), 56-70. http://dx.doi.org/10. 1016/j.bar.2009.11.001

Castro, G. M. De, \& Sáez, P. L. (2008). Intellectual capital in high-tech firms: The case of Spain. Journal of Intellectual Capital, 9(1), 25-36. http://dx.doi.org/10.1108/14691930810845786

Covin, J. G., \& Slevin, D. P. (1989). Strategic management of small firms in hostile and benign environment. Strategic Management Journal, 10, 75-87. http://dx.doi.org/10.1002/smj.4250100107

Creswell, J. W. (2003). A framework for design. In Research design: qualitative, quantitative, and mixed methods approaches (2nd ed., pp. 2-26). New Delhi: Sage Publications, Inc.

Denicolai, S., Zucchella, A., \& Strange, R. (2014). Knowledge assets and firm international performance. International Business Review, 23(1), 55-62. http://dx.doi.org/10.1016/j.ibusrev.2013.08.004

Díez, J. M., Ochoa, M. L., Prieto, M. B., \& Santidrián, A. (2010). Intellectual capital and value creation in Spanish firms. Journal of Intellectual Capital, 11(3), 348-367. http://dx.doi.org/10.1108/14691931 011064581

Fornell, C., \& Larcker, D. F. (1981). Evaluating structural equation models with unobservable variables and measurement error. Journal of Marketing Research, 18(1), 39-50. http://dx.doi.org/10.2307/3151312

Gogan, L. M., \& Draghici, A. (2013). A Model to evaluate the intellectual capital. Procedia Technology, 9, 867-875. http://dx.doi.org/10.1016/j.protcy.2013.12.096

Gowthorpe, C. (2009). Wider still and wider? A critical discussion of intellectual capital recognition, measurement and control in a boundary theoretical context. Critical Perspectives on Accounting, 20(7), 823-834. http://dx.doi.org/10.1016/j.cpa.2008.09.005

Huang, K. P., Wang, K. Y., Chen, K. H., \& Yien, J. M. (2011). Revealing the effects of entrepreneurial orientation on firm performance: A conceptual approach. Journal of Applied Science, 11(16), 3049-3052. http://dx.doi.org/10.3923/jas.2011.3049.3052

Joseph F. Hair, J., Hult, G. T. M., Ringle, C. M., \& Sarstedt, M. (2014). A primer on partial least squares structural equation modeling (PLS-SEM). California: Sage Publications, Inc.

Kamukama, N., Ahiauzu, A., \& Ntayi, J. M. (2010). Intellectual capital and performance: Testing interaction effects. Journal of Intellectual Capital, 11(4), 554-574. http://dx.doi.org/10.1108/14691931011085687

Kaplan, R. S., \& Norton, D. P. (1992). The balanced scorecard-measurement that drive performance. Harvard Business Review, 71-79.

Keh, H. T., Nguyen, T. T. M., \& Ng, H. P. (2007). The effects of entrepreneurial orientation and marketing information on the performance of SMEs. Journal of Business Venturing, 22(4), 592-611. http://dx.doi.org/ 10.1016/j.jbusvent.2006.05.003

Knight, G. A. (1997). Cross-cultural reliability and validity of a scale to measure firm entrepreneurial orientation. Journal of Business Venturing, 12(3), 213-225. http://dx.doi.org/10.1016/S0883-9026(96)00065-1 
Lu, W. M., \& Hung, S. W. (2011). Exploring the operating efficiency of Technology Development Programs by an intellectual capital perspective-A case study of Taiwan. Technovation, 31(8), 374-383. http://dx.doi.org/ 10.1016/j.technovation.2010.10.008

Lumpkin, G. T., \& Dess, G. G. (1996). Clarifying the entrepreneurial orientation construct and linking it to performance. The Academy of Management Review, 21(1), 135-172.

Lumpkin, G. T., \& Dess, G. G. (2001). Linking two dimensions of entrepreneurial orientation to firm performance: The moderating role of environment and industry life cycle. Journal of Business Venturing, 16, 429-451. http://dx.doi.org/10.1016/S0883-9026(00)00048-3

Lyon, D. W., Lumpkin, G. T., \& Dess, G. G. (2000). Enhancing entrepreneurial orientation research: Operationalizing and measuring a key strategic decision making process. Journal of Management, 26(5), 1055-1085. http://dx.doi.org/10.1177/014920630002600503

Mahmood, R., \& Hanafi, N. (2013). Entrepreneurial orientation and business performance of women-owned small and medium enterprises in Malaysia: Competitive advantage as a mediator. International Journal of Business and Social Science, 4(1), 82-91.

Marcin, K. (2013). Intellectual capital as a key factor of socio-economic development of regions and countries. Procedia Economics and Finance, 6(13), 288-295. http://dx.doi.org/10.1016/S2212-5671(13)00142-1

McPhail, K. (2009). Where is the ethical knowledge in the knowledge economy? Critical Perspectives on Accounting, 20(7), 804-822. http://dx.doi.org/10.1016/j.cpa.2008.09.004

Miller, D. (1983). The correlates of entrepreneurship in three types of firms. Management Science (pre-1986), 29(7), 770. http://dx.doi.org/10.1287/mnsc.29.7.770

Milovanović, B. M., \& Galetić, F. (2008). Linking entrepreneurial orientation with the performance of Croatian hotel industry. In 4th International Conference "An Enterprise Odyssey: Tourism-Governance and Entrepreneurship" (pp. 1-7). Cavtat.

Nieves, J., \& Haller, S. (2014). Building dynamic capabilities through knowledge resources. Tourism Management, 40, 224-232. http://dx.doi.org/10.1016/j.tourman.2013.06.010

Nieves, J., Quintana, A., \& Osorio, J. (2014). Knowledge-based resources and innovation in the hotel industry. International Journal of Hospitality Management, 38, 65-73. http://dx.doi.org/10.1016/j.jhhm.2014.01.001

Norreklit, H. (2000). The balance on the balanced scorecard a critical analysis of some of its assumptions. Management Accounting Research, 11(1), 65-88. http://dx.doi.org/10.1006/mare.1999.0121

Pratono, A., Wee, T. C., Syahchari, D. H., Tyaznugraha, A., Mat, N. K. N., \& HadiatiFitri. (2013). The Direct Effect of Entrepreneurial Orientation and Innovation Success on Firm Performance. American Journal of Economics, 3(1), 1-6.

Rauch, A., Wiklund, J., Lumpkin, G. T., \& Frese, M. (2009). Entrepreneurial orientation and business performance: An assessment of past research and suggestions for the future. Entrepreneurship Theory and Practice, 1-54. http://dx.doi.org/10.1111/j.1540-6520.2009.00308.x

Ringle, C. M., Sarstedt, M., \& Straub, D. W. (2012). Editor's comments: A critical look a use of PLS-SEM in MIS Quartely. MIS Quarterly, 36(1), 2-7.

Roos, G., \& Roos, J. (1997). Measuring your company's intellectual performance. Long Range Planning, 30(3), 413-426. http://dx.doi.org/10.1016/S0024-6301(97)90260-0

Sekaran, U., \& Bougie, R. (2013). Research methods for business: A skill-building approach (6th ed.). West Sussex: John Wiley \& Sons Ltd.

Shane, S., Mcgrath, R., \& Macmillan, I. (2009). Is entrepreneurial orientation a global construct? A multi-country study of entrepreneurial orientation, growth strategy, and performance. The Journal of Business Inquiry, 8, 12-25.

Small and Medium Enterprises Report. (2009). Report of the vision 2020 national technical working group on small and medium enterprises (SMEs). Abuja. Retrieved from http://www.npc.gov.ng/vault/files/smalland mediumenterprisesntwgreport.pdf

Spillan, J., \& Parnell, J. (2006). Marketing resources and firm performance among SMEs. European Management Journal, 24(2-3), 236-245. http://dx.doi.org/10.1016/j.emj.2006.03.013 
Sumedrea, S. (2013). Intellectual capital and firm performance: A Dynamic relationship in crisis time. Procedia Economics and Finance, 6(13), 137-144. http://dx.doi.org/10.1016/S2212-5671(13)00125-1

Suwignjo, P., Bititci, U., \& Carrie, A. (2000). Quantitative models for performance measurement system. International Journal of Production Economics, 64(1-3), 231-241. http://dx.doi.org/10.1016/S0925-5273 (99)00061-4

Sydler, R., Haefliger, S., \& Pruksa, R. (2013). Measuring intellectual capital with financial figures: Can we predict firm profitability? European Management Journal.

Walsh, K., Enz, C. A., \& Canina, L. (2008). The Impact of Strategic Orientation on Intellectual Capital Investments in Customer Service Firms. Journal of Service Research, 10(4), 300-317. http://dx.doi.org/10. $1177 / 1094670508314285$

Wang, C. L. (2008). Entrepreneurial orientation, learning orientation, and firm performance. Entrepreneurship Theory and Practice, 44, 635-657. http://dx.doi.org/10.1111/j.1540-6520.2008.00246.x

Wang, H., Yen, Y., Hong, J., \& Tsai, Y. (2001). Empirical evidence between corporate entrepreneurial orientation and performance: A perspective of multidimensional construct.

Wiklund, J., \& Shepherd, D. (2003). Knowledge-based resources, entrepreneurial orientation, and the performance of small and medium-sized businesses. Strategic Management Journal, 24(13), 1307-1314. http://dx.doi.org/10.1002/smj.360

Wiklund, J., \& Shepherd, D. (2005). Entrepreneurial orientation and small business performance: A configurationally approach. Journal of Business Venturing, 20(1), 71-91. http://dx.doi.org/10.1016/j.jbus vent.2004.01.001

Yıldız, S., Meydan, C., \& Güner, M. (2014). Measurement of intellectual capital components through activity reports of companies. Procedia-Social and Behavioral Sciences, 109, 614-621. http://dx.doi.org/10.1016/j. sbspro.2013.12.516

\section{Copyrights}

Copyright for this article is retained by the author(s), with first publication rights granted to the journal.

This is an open-access article distributed under the terms and conditions of the Creative Commons Attribution license (http://creativecommons.org/licenses/by/3.0/). 